\title{
Gender-related family head schooling and Aedes aegypti larval breeding risk in Southern Mexico
}

\author{
Rogelio Danis-Lozano, MSC, ${ }^{(1)}$ Mario H Rodríguez, MD, PhD, (2) \\ Mauricio Hernández-Avila, MD, PhD. ${ }^{(3)}$
}

\begin{abstract}
Danis-Lozano R, Rodríguez MH, Hernández-Avila M. Gender-related family head schooling and Aedes aegypti larval breeding risk in Southern Mexico.

Salud Publica Mex 2002;44:237-242.

The English version of this paper is available too at: http://www.insp.mx/salud/index.html
\end{abstract}

\begin{abstract}
Objective. To investigate if family head genre-associated education is related to the risk of do miciliary A edes aegypti larval breeding in a dengue-endemic village of Southern Mexico. Material and Methods A family head was considered to have a low education level if he/she had not completed elementary school. To estimate larval breeding risk within each household, a three-category Maya index was constructed using a weighted estimation of controllable and disposable do mestic water containers.A socio-economic index was constructed based on household construction characteristics. Results Low-level education of either family head was associated to higher larval breeding risk. Households with low-educated mothers had more lar val breeding containers. These associations persisted after adjusting for household socio-economic level. Conclusions These results indicate that households with female family heads with low education levels accumulate more containers that favor Ae. aegypti breeding, and that education campaigns for dengue control should be addressed to this part of the population.The English version of this paper is available too at: http://www.insp.mx/salud/index.html
\end{abstract}

Key words:A edes aegypti;larval breeding; gender; education; Mexico
Danis-Lozano R, Rodríguez MH, Hernández-Avila M. Escolaridad con relación al género de los jefes de familia y el riesgo de cría de Aedes aegypti en el sur de México.

Salud Publica Mex 2002;44:237-242.

El texto completo en inglés de este artículo también está disponible en: http://www.insp.mx/salud/index.html

\section{Resumen}

Objetivo. Investigar si la escolaridad asociada con el género de los jefes de familia de una localidad endémica de dengue en el sur de México estaba relacionada con el riesgo de cría intradomiciliaria de Aedes aegypti. Material y métodos. Se consideró que un jefe de familia tenía baja educación si él/ella no había completado la educación primaria. Para estimar el riesgo de cria larvaria en cada domicilio se construyó un Indice Maya de tres categorías a partir de la estimación ponderada de recipientes controlables y desechables. Se construyó un índice socioeconómico basado en los materiales de construcción de la casa. Resultados $N$ iveles bajos de educación de los jefes de familia se asociaron con niveles altos de riesgo de cría de larvas de mosquitos. Pero las casas con jefas de familia con baja educación tuvieron más recipientes en riesgo para la cría de larvas. Estas observaciones no se modificaron después de ajustar por el nivel socioeconómico. Conclusiones Estos resultados indican que las casas con jefas de familia de baja educación acumulan más recipientes que favorecen la cría de lar vas Ae. aegypti, y que sería conveniente que las campañas de educación para el control del dengue se dirigieran hacia esta parte de la población. El texto completo en inglés de este artículo también está disponible en:http://www.insp.mx/ salud/index.html

Palabras clave: Aedes aegypti; cría de larvas; género; educación; México

This work was financially supported by the Ministry of Health of Mexico.

(1) Centro de Investigación de Paludismo, Instituto Nacional de Salud Pública, Tapachula, Chiapas, México.

(2) Centro de Investigación sobre Enfermedades Infecciosas, Instituto N acional de Salud Pública, Cuernavaca, Morelos, México.

(3) Centro de Investigación en Salud Poblacional, Instituto N acional de Salud Pública, Cuernavaca, Morelos, México.

Received on: July 3,2001 • Accepted on: N ovember 9, 2001

Address requests reprints to: Mario H Rodríguez, Centro de Investigación sobre Enfermedades Infecciosas, Instituto N acional de Salud Pública, Avenida Universidad 655, Col. Santa María A huacatitlán, 62508, Cuernavaca, Morelos, México.

E-mail: mhenry@ insp3.insp.mx 
$A$ edes aegypti, the main vector of dengue fever in the Americas, is well adapted to urban environments, where person-made water containers provide suitable habitats for their larvae to breed. ${ }^{1}$ In tropical areas, discarded metal drums and concrete-built tanks, used to collect and storage water, are the most frequent habitats for these larvae. Other containers such as flowerpots as well as discarded tires and bottles that accumulate in backyards are also used by this mosquito to lay its eggs, when rainfall provides the necessary water substrate. The use of metal drums and concrete tanks for water storage is used as a remedy to inadequate water supply services, but in places where water is efficiently provided, the use of containers for daily use is determined by culturally-dictated practices. ${ }^{2}$

Gender has an important effect on the distribution of activities within the household. As family heads are more frequently males, house chores are more frequently carried out by housewives. ${ }^{3}$ Although it is expected that socio-economic factors may have an important effect on housing conditions, including water storage practices, a gender-related labor distribution within the family suggests that these conditions could be differentially affected by the educational level of its dwellers. ${ }^{3}$ We present herein the results of a study, conducted in Southern Mexico, to investigate whether the level of schooling of the male and female family heads was associated to the risk for the presence of water containers suitable for Ae. aegypti larval breeding within households. These observations may provide useful information to better target future antidengue educational programs by health authorities.

\section{Material and Methods}

The study was carried out in Huixtla, $\left(92^{\circ} 97^{\prime} \mathrm{N} ; 1^{\circ}\right.$ $8 \mathrm{~W})$ a city where dengue fever is endemic, with 45000 inhabitants located on the Pacific Ocean coastal plain of Chiapas, Southern Mexico. A cross-sectional study was carried out between July and August 1994. The locality was divided into four areas (center, intermediate, peripheral and city edges). In each area 62 households were randomly selected for the study (25\% of total). Both male and female family heads were interviewed and a questionnaire to investigate socio-demographic conditions was applied. The questionnaire obtained information on house ownership, both family heads' age, schooling and occupation, as well as the number of persons living in the house. A family head was considered to have a low level education if he or she had not completed six years of formal elementary school.
Following the interview, an entomological survey within the household and its backyard was carried out by the same personnel that conducted the interview. All possible water containers with or without Ae. aegypti larvae were registered and classified as controllable and disposable ones. Controllable containers were those in use in the household that could be manipulated by man to avoid mosquito larval breeding. These included: concrete tanks, metal drums, flower pots, aluminum tanks, small buckets, and other plastic containers used to carry or storage water. Disposable containers, abandoned or stored in the backyard, were those not in use in the household but, in the event of rainfall, could become breeding sites; these included: tires, cans, tubs, etc. Bottles were excluded because they contributed with less than $0.01 \%$ to the total number of disposable containers.

We used the Maya index (MI) to estimate larval breeding risk. ${ }^{4}$ Briefly, this index was constructed for each household using two indicators: the Breeding Risk Indicator (BRI) and the Hygiene Risk Indicator (HRI). Both indicators were categorized as high, medium and low according to tertiles distribution. To construct the Maya index, both, BRI and HRI values of each household, were plotted in a $3 \times 3$ matrix where high Ae. aegypti larval breeding risks categories corresponded to: BRI3/HRI3, BRI3/HRI2 and BRI2/HRI3, medium breeding risks were: BRI1/HRI3, BRI2/HRI2, BRI3/ HRI1, and low breeding risks were: BRI1/HRI1, BRI2/HRI1 and BRI1/HRI2. The BRI was obtained by dividing the number of controllable containers in the house by the mean number of Ae. aegypti larvae-positive controllable containers per house among the surveyed households in the community. The HRI was obtained by dividing the number of disposable containers by the mean number of Ae. aegypti larvae-positive disposable containers per house among the surveyed households in the community.

The socio-economic level of each household was estimated from the following characteristics: type of floor, walls and roof, and water supply. ${ }^{5}$ A socio-economic index was constructed, including low, medium and high levels according to the household's percentil distribution. An exploratory analysis was conducted on each variable to obtain simple frequencies and histograms. Due to the non-normal distribution of the two indicators BRI and HRI, Spearman's correlations were calculated for the number of total containers per household and the number of positive containers per household. After documenting significant correlations between the BRI and HRI indicators among the households surveyed, these indicators were used to in- 
vestigate the probability of the presence of Ae. aegypti positive containers per household. This probability was obtained by dividing the proportion of positive households classified as corresponding to high and medium BRI or HRI category by the proportion of BRI or HRI low category households. To assess the relationship between demographic factors and the risk of having positive larval habitats we used a polytomous logistic regression model. This statistical procedure can be used as an extension of the logistic regression model for a response variable with three categories. The covariate coefficients are interpreted as odds ratios, as they estimate the change in the log odds of having a medium or high Maya index value by unit change in the independent variable. All analyses were conducted using the STATA statistical package.

\section{Results}

A total of 1965 containers with potentiality for larval breeding were identified in the 248 houses surveyed, corresponding to a mean of 7.9 containers per household. Of these, $44.6 \%$ were controllable $(10.1 \%$ of these had Ae. aegypti larvae), and $55.4 \%$ were disposable ones (19.1\% of these had Ae. aegypti larvae) (Table I). More than $50 \%$ of controllable containers were buckets; metal drums, plastic containers and tubs contributed with $5.61 \%$ each one. Tires represented $30.7 \%$ and cans $21.6 \%$ of all disposable containers. Regarding entomological and larval breeding indexes, the proportion of houses with low, medium and high MI category were $0.44(n=109), 0.24(n=59)$ and $0.32(n=80)$, respectively. Spearman's correlations against number of total containers and the number of positive containers per household resulted in a positive correlation for controllable and discarded containers $(r=0.40, p<0.0001$ for BRI, and $r=0.54, p<0.0001$ for HRI).

Houses with high and medium BRI levels were 32 $(p<0.01)$ and 8.0 (NS) times more likely to have Ae. aegypti positive containers than houses of low BRI level. Similarly, high and medium HRI level houses were 58 and 12 times more likely to have positive containers than those of low HRI level (Table II).

Twenty-three households corresponded to high, 146 to medium and 79 to low socio-economic category levels. Low socio-economic level households were two times more likely to be included in the medium MI and three times more likely to be included in the high MI categories than in the lower MI $(O R=1.95,95 \%$ CI 0.6-6.4 and $O R=3.45,95 \%$ CI 0.9-11.9, respectively). Also, medium socio-economic level households were 1.7 more likely to be included in the high MI categories than in the low $\mathrm{MI}(\mathrm{OR}=1.7,95 \% \mathrm{CI} 0.3-5.2)$. After
Table I

\section{W ater containers and PResence of Aedes aegypty LARVAE IN 248 HOUSEHOLdS IN HUIXTLA, Chiapas, Mexico, 1994}

\begin{tabular}{lrrrr} 
Container type & $\begin{array}{c}\text { Total } \\
\text { number }\end{array}$ & $\begin{array}{c}\text { Number } \\
\text { with larvae }\end{array}$ & $\begin{array}{c}\text { \% with } \\
\text { larvae }\end{array}$ & $\begin{array}{c}\text { \% of total larvae } \\
\text { in the survey }\end{array}$ \\
Controllable & 878 & 89 & 10.13 & 29.96 \\
\hline Bucket & 445 & 49 & 11.01 & 16.49 \\
\hline Small bottles & 6 & 6 & 100 & 2.02 \\
\hline 200-liter metal drums & 37 & 5 & 13.51 & 1.68 \\
\hline Plastic containers & 90 & 5 & 5.55 & 1.68 \\
\hline Plastic bathtubs & 54 & 5 & 9.25 & 1.68 \\
\hline Ceramic pots & 24 & 4 & 16.6 & 1.34 \\
\hline Metal can lids & 47 & 4 & 8.51 & 1.34 \\
\hline Tanks & 102 & 4 & 3.92 & 1.34 \\
\hline Casserole pots & 7 & 3 & 42.85 & 1.01 \\
\hline Plant pot bases & 43 & 3 & 6.97 & 1.01 \\
\hline W ells & 23 & 1 & 4.34 & 0.33 \\
\hline Disposable & 48 & 9 & 18.75 & 3.03 \\
\hline W ater storage containers 424 & 69 & 16.27 & 23.23 \\
\hline Tires & 111 & 64 & 57.65 & 21.54 \\
\hline Cans & 282 & 45 & 15.95 & 15.15 \\
\hline O thers & 222 & 21 & 9.45 & 7.07 \\
\hline Total & 1087 & 208 & 19.13 & 70.04 \\
\hline
\end{tabular}

adjusting for the education level of family heads, the multivariate model indicated that low economic level households were 1.5 more likely to be included in the medium MI and 2.2 more likely to be included in high MI categories than in the lower MI $(O R=1.5,95 \% \mathrm{CI}$ 0.4-5.2 and $O R=2.2,95 \%$ CI 1.6-7.8, respectively). On the other hand, medium economic level households were 1.1 more likely to be included in the high MI category than in the low MI $(O R=1.11,95 \%$ CI 0.34-3.6). The analysis of education level of household family heads and the frequency and abundance of Ae. aegypti larval habitats, showed that in 43 out of 248 households included in the study, both male and female household family heads had completed primary school (17.3\%); in 78 both family heads did not complete primary school (31.4\%), in 106 the male completed primary school but not the female $(42.7 \%)$, and in 21 the female completed primary school but not the male $(8.4 \%)$.

The results of the bivariate analysis are presented in Table III. Households where the mother did not complete primary school were two times more likely to be included in the category of medium MI and three times 
Table II

Distribution of AEDES AEgYPTI POSITIVE hOUSEHOLDS AND DISPOSABLE CONTAINERS WITH LARVAE ACCORDING

TO THEIR BREEDING RISK INDICATOR

AND HYGIENE RISK INDICATOR IN HUIXTLA, Chiapas, Mexico, 1994

\begin{tabular}{cccc}
\multicolumn{4}{c}{ Presence of Ae. aegypti } \\
Total containers & Number & Number & Prevalence of \\
per households & positive & positive & positive Households \\
$\quad$ surveyed & households & containers & $(95 \% \mathrm{Cl})^{*}$
\end{tabular}

BRI Category

\begin{tabular}{lcrrc} 
Low & $1 / 77$ & 1 & 1 & $1.2 ;(0.03-7.2)$ \\
\hline Medium & $86 / 56$ & 5 & 5 & $8.9 ;(2.9-19.6)$ \\
\hline High & $791 / 115$ & 37 & 66 & $32.1 ;(23.7-41.5)$
\end{tabular}

HRI Category

\begin{tabular}{lcrrr} 
Low & $59 / 87$ & 1 & 1 & $1.1 ;(0.02-2.6)$ \\
\hline Medium & $81 / 55$ & 7 & 9 & $12.7 ;(5.2-24.4)$ \\
\hline High & $947 / 106$ & 62 & 151 & $58.4 ;(48.5-67.9)$ \\
\hline Total & $1965 / 248$ & 113 & 233 &
\end{tabular}

* $95 \% \mathrm{Cl}: 95 \%$ confidence interval

$\mathrm{BRI}$ : breeding risk indicator

HRI: hygiene risk indicator

times more likely to be included in the high MI than in the lower MI category $(\mathrm{OR}=2.7,95 \% \mathrm{CI} 1.3-6.0$ and $\mathrm{OR}=3.2,95 \% \mathrm{CI} 1.6-6.6$, respectively). Households were only the male family head completed elementary school were almost three times more likely to be included in the high MI category $(O R=2.4,95 \%$ CI 0.9 6.1 and $O R=2.8,95 \%$ CI 1.2-6.0, respectively). Although the analysis indicated that households where only the female had completed primary school were 1.6 and 1.7 times more likely to be included in medium and high MI categories, this was not statistically significant. When adjusted for household economic level in the multivariate polytomous regression analysis, these observations remained unchanged (Table III). This analysis indicated that households where only females completed primary school were not more likely to be included within the medium and high MI categories $(O R=0.9,95 \%$ CI $0.3-3.3$ and $O R=0.8 .95 \%$ CI $0.3-2.6$, respectively).

\section{Discussion}

Aedes aegypti is well adapted to domestic and peridomestic environments where larval breeding occurs in almost any exposed recipient containing water. ${ }^{6-19}$ Larval breeding also occurs in containers specifically used for water storage, a condition facilitated by the lack of proper water supply. Accordingly, in this study Ae. Aegypti larval breeding in households was represented by both controllable and disposable containers, as documented in other dengue endemic areas. ${ }^{10-13}$ The contribution of controllable containers to larval breeding was high, but larval breeding in disposable con-

Table III

Aedes aegypti larval breeding RiSK, estimated by polytomous LOGISTIC Regression,

AS A FUNCTION OF EDUCATION AND SOCIO-ECONOMIC LEVELS of family heads in huixtla, Chiapas, MeXico, 1994

\begin{tabular}{|c|c|c|c|c|c|c|c|c|}
\hline & \multicolumn{4}{|c|}{$\begin{array}{l}\text { Bivariate unadjusted model } \\
\text { Family head education }\end{array}$} & \multicolumn{4}{|c|}{$\begin{array}{l}\text { Multivariate adjusted model } \\
\text { Family head education }\end{array}$} \\
\hline & $\begin{array}{l}\text { Both } \\
\text { educated } \\
(n=43)^{*}\end{array}$ & $\begin{array}{c}\text { educated } \\
\text { - low educated } \\
(n=21)\end{array}$ & $\begin{array}{l}\text { - low educated } \\
\text { - educated } \\
\text { ( } n=106)\end{array}$ & $\begin{array}{l}\text { Both with low } \\
\text { education } \\
(n=78)\end{array}$ & $\begin{array}{l}\text { Both } \\
\text { educated }\end{array}$ & $\begin{array}{c}\text { educated } \\
\text { _ low educated }\end{array}$ & $\begin{array}{l}\text { _ low educated } \\
\text { _ educated }\end{array}$ & $\begin{array}{l}\text { Both with low } \\
\text { education }\end{array}$ \\
\hline Medium risk vs. low risk & 1.0 & $1.7(0.5-5.4)^{\ddagger}$ & $2.4(0.9-6.1)$ & $2.7(1.3-6.0)$ & 1.0 & $0.9(0.3-3.3)^{\S}$ & $2.7(0.8-5.8)^{\S}$ & $2.6(1.2-5.9)^{\S}$ \\
\hline \multirow[t]{3}{*}{ High risk vs. Low } & 1.0 & $1.6(0.5-5.1)$ & $2.8(1.2-6.0)$ & $3.2(1.6-6.6)$ & 1.0 & $0.8(0.3-2.6)^{\S}$ & $2.3(1.0-5.6)^{\S}$ & $2.8(1.3-5.8)^{\S}$ \\
\hline & \multicolumn{4}{|c|}{ Socio-economic level } & \multicolumn{4}{|c|}{ Socio-economic level } \\
\hline & \multicolumn{2}{|c|}{$\begin{array}{l}\text { High } \\
(n=23)\end{array}$} & $\begin{array}{l}\text { dium } \\
146)\end{array}$ & $\begin{array}{c}\text { Low } \\
(n=79)\end{array}$ & $\mathrm{High}$ & \multicolumn{2}{|c|}{ Medium } & LoW \\
\hline Medium risk vs. low risk & \multicolumn{2}{|c|}{1.0} & $1.4-2.6)$ & $1.7(0.3-5.2)$ & \multicolumn{3}{|c|}{$0.7(0.2-2.1)^{\#}$} & $1.1(0.3-3.6)^{\#}$ \\
\hline High risk vs. low risk & \multicolumn{2}{|c|}{1.0} & $.6-6.4)$ & $3.4(0.9-11.9)$ & \multicolumn{3}{|c|}{$1.5(0.4-5.2)^{\#}$} & $2.2(1.6-7.8)^{\#}$ \\
\hline \multicolumn{9}{|c|}{$\begin{array}{l}\text { * } n=\text { number of households in the category } \\
\neq \mathrm{CI} \text {, C onfidence intervals } \\
\text { \& Adusted for economic level } \\
\text { \# Ajusted for education level }\end{array}$} \\
\hline
\end{tabular}


tainers was higher (an estimated $70 \%$ of total larval production) similar to that reported elsewhere. ${ }^{1}$

As larval breeding sites increase in houses that accumulate refuse, including discarded containers, ${ }^{13-15}$ dengue transmission by Ae. aegypti has been associated to poor hygienic conditions, which in turn may be associated to low socioeconomic levels and to low schooling of the house dwellers. ${ }^{16}$ The data presented here indicate that the risk of dengue transmission, estimated by MI (an estimation of the larval breeding risk in relation to hygiene levels), is higher in households of low socioeconomic level, similar to the situation reported in other areas. ${ }^{13} \mathrm{~A}$ correlation between low socioeconomic and schooling levels has also been reported. ${ }^{1,13}$ To our knowledge, this is the first report dealing with the association of low schooling with the presence of dengue breeding sites. Additionally, a more important effect of the education level of the female family head was documented.

Several indexes have been instrumental to estimating dengue transmission risk, including the traditional house, recipient, and Breteau indexes. ${ }^{17}$ However, these indexes are indicative of the global transmission risk in the community. Within a community, not all houses have the same potential for larval breeding, and the identification of those houses likely to have high larval production is important to better direct control activities. The Maya index has been successfully used to estimate Ae. aegypti larval breeding in dengue endemic areas. ${ }^{4}$ The classification of potencial breeding sites in controllable and disposable materials incorporates a domestic hygiene index witthing the MI. Furthermore, this indicator was a predictive element in the breeding risk matrix constructed (Maya index), and indicated that the likelihood of the presence of Ae. Aegypti larvae in high and medium HRI houses was 32 and 8-fold than in houses with low HRI.

The analysis of the effect of schooling in adult house dwellers, represented by male and female family heads, indicated that low education levels are associated to higher MI. But more important, if at least one of the family heads has completed primary school, medium and high MI occur when the housewife is the uneducated partner. Higher MI was also associated to low socioeconomic household levels. As low schooling is common in precarious socioeconomic conditions, an adjustment was necessary to better estimate the effect of schooling. In a multiple polytomous regression analysis, after adjusting for socioeconomic conditions, the association of medium to high MI and low schooling persisted, for both family heads or the housewife only.

A limited number of epidemiological studies on infectious diseases in relation to gender issues are available. ${ }^{18}$ These studies indicate the importance of gender-related activities on women's susceptibility to the infection and their participation on control activities. Thus, in Egypt, low-educated and economically dependent women had little knowledge on malaria and schistosomiasis and less access to information and preventive measures. ${ }^{18}$ In Bolivia, although most women are familiar with triatomine bugs inside their houses, low-educated women are less likely to identify these insects as Chagas disease vectors. ${ }^{19}$ Similar attitudes were observed in our study; although housewives knew of the presence of Ae. aegypti larvae in their houses, they were unaware of their potentiality as biting mosquitoes, and less of their potentiality as dengue vectors. Also, in Kenya, the usage of insecticide-impregnated bednets was significantly related to the mothers' educational level, ${ }^{20}$ and a comprehensive review of the literature noted that worldwide, for each year of mother schooling a decrement of 7-9\% in childhood mortality rate was documented. ${ }^{21}$ These studies highlight the role of women in disease prevention and the need of their education.

Cultural conventions imposing different social roles on men and women are determinant for their different exposure to vector-borne diseases. Thus, in India, the risk of malaria infection in men is determined by their exposure in working settings outside their home, while women, having the responsibility of the house chores, are exposed in or nearby household compounds. ${ }^{3,22}$ This social structure may certainly be responsible for a more important participation of women in disease control activities within their households. Women contribution to the community welfare should be addressed using a holistic approach, in which along with the recognition of the social conventions determining their role in family care, their special needs and direct participation in environmental keeping are fully recognized and properly promoted.

The results of the present study suggest that dengue control in southern Mexico could benefit with the participation of female family heads in eliminating larval breeding. As gender roles are difficult to change by direct outside interventions, they also indicate that the best strategy for this purpose could be educational campaigns especially directed to this sector of the population. 


\section{Acknowledgments}

We thank technicians René Monzón-Vera, Luis Domínguez-Sibaja, Crecencio Díaz-Espinoza, Amilcar Zúñiga-Ambrocy, José Luis Espinoza, and Francisco Maldonado-Vázquez for their assistance in field work.

\section{References}

1. Lloyd L, W inch P, O rtega-C anto J, Kendall C. Results of a communitybased Aedes aegypti control program in Merida, Yucatan, Mexico. Am J Trop Med Hyg 1992;46:635-642.

2.T idwell MA,W illiams DC, C arvalho-Tidwell T, Peña CJ, G winn TA, Focks DA et al. Baseline data on Aedes aegypti populations in Santo Domingo, Dominican Republic. J Am Mosq Control Assoc 1990;6:514-522.

3. Rathgeber EH,Vlassoff C. Gender and tropical diseases:A new research focus. Soc Sci Med 1993;37:513-520.

4. Miller JE, Martínez-Balanzar A, G azga-Salinas D. W here Aedes aegypti live in Guerrero; using the Maya index to measure breeding risk. En: Halstead $\mathrm{SB}, \mathrm{G}$ ómez-Dantés $H$. ed. Denque: A worldwide problem, a common strategy. México, D.F.: Ministry of Health, Mexico, and Rockefeller Foundation, 1992:311-317.

5. Bronfman M, Guiscafré $H, C$ astro V, C astro R, Gutiérrez G. Strategies for improving the therapeutic patterns used in acute diarrhea in primary medical care units. II. The measurement of inequality: A methodologic strategy analysis of the socioeconomic features of the sample.Arch Invest Med 1988;19:351-360.

6. Moore-Chester G, C line-Barnett L, Ruiz-Tiben E, Lee D, Romney-liseph $H$, Rivera-Correa E. Aedes aegypti in Puerto Rico: Environmental determinants of larval abundance and relation to dengue virus transmission. Am J Trop Med Hyg 1978 27:1225-1231.

7. Slosek J. A edes aegypti mosquitoes in the Americas: A review of their interaction with the human population. Soc Sci Med 1986;23:249-252.

8. Kuno $G$. Review of the factors modulating dengue transmission. Epidemiol Rev 1995;17:321-335.

9. Tun-Lin W, Kay BH, Barnes A.The premise condition index: A tool for streamlining surveys of A edes aegypti.A m JTrop Med Hyg 1995;53: 591-594.
10. Focks DA, Sackett SR, Bailey DL, Dame DA. O bservations on container-breeding mosquitoes in $\mathrm{N}$ ew $\mathrm{O}$ rleans, Louisiana, with an estimate of the populations density of Aedes aegypti (L.) A m JTrop Med Hyg 1981;30:1329-1335.

11. SamarawickremaW A, Sone F, Kimura E, Self LS, C ummings RF, Paulson GS. The relative importance and distribution of Aedes polynesiensis and Aedes aegypti larval habitats in Samoa. Med Vet Entomol 1993;7:27-36.

12. N athan MB. C ritical review of Aedes aegypti control programs in the $C$ aribbean and selected neighboring countries. J Am Mosq Control Assoc 1993:9:1-7.

13. Barrera R,A vila J,G onzález-Téllez S. Unreliable supply of potable water and elevated Aedes aegypti larval indices; a causal relationship. J Am Mosq Control Assoc 1993:9:189-195.

14. Ko YC, Chen MJ,Yeh SM.The predisposing and protective factors against dengue virus transmission by mosquito vector. Am J Epidemiol 1992; 136:214-220.

15. Fernández-Salas I, Flores-Leal A. El papel del Aedes aegypti en la epidemiología del dengue en México. Salud Publica Mex (Supl) 1995;37: 545-552.

16. Rodríguez-Figueroa L, Rigau-Pérez JG, Suárez EL, Reiter P. Risk factors for dengue infection during an outbreak inYanes, Puerto Rico, in 1991.Am JTrop Med Hyg 1995;52:496-502.

17. Breteau H. La fievre jaune en A frique Accidentale Francaise. Un aspect de la medicine preventive massive. Bull World Health 0 rgan 1954;11: 453-481.

18.Vlassoff C, Bonilla E. G ender-related differences in the impact of tropical diseases on women:W hat do we know? J Biosoc Sci 1994;26:37-53.

19. Weinke TH, Veberreiter K, Alexander M. Cardiac morbidity due to Chagas disease in a rural community in Bolivia. Epidemiol Infect 1988;101:655-660.

20. Marsh VM, Mutemi W, Some ES, Haaland A, Snow RW. Evaluating the community education programme of an insecticide-treated bednet trial on the Kenyan coast. Health Policy Plann 1996;11:280.

21. Cleland J, Ven Ginneken JK. Maternal education and child survival in developing countries:The search for pathways of influence. Soc Sci Med 1988;27:1357.

22. Reuben R, Panicker KN .A study of human behaviour influencing manmosquito contact and of biting activity on children in a so uth Indian village community. Ind J Med Res 1979;70:723-729. 